\title{
Technological intensity of Serbian manufacturing industry in Pre-Covid-19 period
}

\author{
Article history: \\ Received: 17 November 2020 \\ Sent for revision: 10 December 2020 \\ Received in revised form: 17 December 2020 \\ Accepted: 22 December 2020 \\ Available online: 31 December 2020
}

\begin{abstract}
This paper analyses technological intesity of Serbian manufacturing sector. The key purpose is to identify development of technological advancment groups (high, medium-high, medium-low and low) during the period of 20102019. The analysis shows that in 2019 the share of high-tech production areas in the total MVA increased to 5\%, which is the best result since 2015. Changes in production correspond to the movement in foreign trade. The coverage of imports by exports of the manufacturing industry, relatively observed in the medium term, is increasing the fastest in the segment of tangible production, which is included in the category of medium-technological complexity. Serbia is not exclusively competitive in the labour intensive stages of production. It is also competitive in a good part of medium-technological complexity production. Finaly, vast FDI inflows and the activities of foreign investors, in good part, drive successful technological restructuring in recent years.
\end{abstract}

Keywords: Technological intensity and structure, manufacturing industry, value added, export, FDI

\section{Tehnološka intenzivnost prerađivačke industrije Srbije u periodu pre Covid-19 pandemije}

Apstrakt: Rad analizira tehnološku intenzivnost prerađivačke industrije Srbije Cilj je identifikovati promene različitih tehnoloških grupa proizvodnje (visoka, srednje-visoka, srednje-niska i niska) od 2010. do 2019. godine. Rezultati

${ }^{1}$ Economics Institute, Belgrade, ivan.nikolic@ecinst.org.rs 
analize pokazuju da je u 2019. udeo visoko-tehnoloških oblasti proizvodnje u ukupnoj dodatoj vrednosti uvećan na 5\%, što je najbolji rezultat od 2015. godine. Promene u proizvodnji korespondiraju spoljnotrgovinskim rezultatima. Pokrivenost uvoza izvozom se relativno posmatrano u srednjem roku, najbrže uvećava u segmentu razmene proizvoda koje ubrajamo u kategoriju srednje tehnološke složenosti. Srbija nije isključivo konkurentna u proizvodnji Low-tech proizvoda. Ona je konkurentna i u dobrom delu proizvodnje proizvoda srednje tehnološke složenosti. Konačno, masivan priliv SDI i aktivnost stranih investitora su dobrim delom odgovorni za uspešno tehnološko restrukturiranje poslednjih godina.

Ključne reči: Tehnološka intenzivnost i struktura, prerađivačka industrija, dodata vrednost, izvoz, SDI

\section{Introduction}

The objective of this paper is to analyse the technological Intensity of Serbian manufacturing industry in Pre-Covid Period. The key purpose is to identify development of technological advancment groups (high, medium-high, medium-low and low) during the period of 2010-2019.

This article does not intend to provide a full description of all relevant details in the technological restructuring in recent years, but should give the interested reader a comprehensive overview of the major in uencing factors for inter alia contribute to Serbia avoiding an industrial decline during 2020, as well.

The fact is that Serbia entered the pandemic with much better overall macroeconomic and more favorable structural indicators compared to previous crises. The package of goverment measures, adopted in record time, has propped up activity in the greatest number of key sectors enabling return to precrisis levels very soon and has preserved production capacities and employment, all of which will enable Serbia to record strong economic growth next year and return to the growth rate of around 4\% p.a. in the medium term.

A significant contribution to this comes from the legacy of of the tangible structural economic and technological improvement, as well, especially in manufacture industry. This can be crucial impact on the development in the new decade.

The pandemic has reinforced some of the trends which preceded it but has also caused massive disruptions and reversed other trends. It is evident that the "new normal" in the postpandemic world will increasingly be driven by the 4th industrial revolution technologies (4IR) and their applications for inclusive and sustainable industrial development. However, the crisis has also presented 48 
challenges across the spectrum of $4 \mathrm{IR}$ development and proved that not everyone is ready to embrace a more digitized existence under the "new normal" (UNIDO, 2020). Hence, 4IR remains the key driver of technological development policy and action. Regarding to mentioned requirements, where is the current position of Serbia?

\section{Related literature}

Development theory has long held that manufacturing is the engine of economic growth and key for a country's development (Kaldor, 1975). This notion is based on the observation that manufacturing activities are typically characterized by high knowledge content and significant opportunities for technological advances (Foteini\&Nelson, 2018).

Moreover, the production of highly sophisticated goods provides the possibility to generate technological spillovers across different sectors, thus boosting the productivity of the entire economic system. Manufacturing could also help to reduce the technological gap promoting the adoption of new technology and the development of high-productivity jobs -as recently pointed out by Rodrik. Thereby, most of new technological developments related to automation (4IR) are builtupon old technologies and manufacturing knowledge, suggesting that building a manufacturing base is still a necessary condition tocatching-up (Haraguchi at al, 2018).

Technological capabilities are fundamental elements of productive capacities and critical to increased productivity, competitiveness and profitability. These capabilities transform assets or resources, into tangible, physical or intangible outputs of greater value (UNCTAD, 2020a).

The transformative potential of technology in production systems is widely recognized, even while the precise configuration and extent of the possible transformation remain unknown. Trends towards higher levels of automation promise greater speed and precision of production as well as reduced exposure to dangerous tasks for employees. New production technologies could help overcome the stagnant productivity of recent decades and make way for more value-added activity. The extent of automation is, however, causing significant anxiety about issues of employment and inequality (WEF, 2017).

\section{Research methodology}

Structural change is a complex phenomenon which includes several stages in macroeconomic recomposition. Technological effort is a critical determinant of 
productivity growth and international competitiveness. However, since it is not spread evenly across the economy, analyses of industry performance and structural change attach much importance to technological criteria (OECD, 2011).

By the means of empirical analysis of the Serbian industry paper disaggregate data into manufacture divisions/groups and observe their growth patterns. Changes in the structure of industrial production can be traced through weighted coefficients, which represent the approximate amount of value added share of each division/group in total value added of the industry. Thus, the effect of unequal production coverage in certain division/group was eliminated.

Aggregation of the manufacturing industry according to technological intensity and based on NACE Rev. 2 at 3-digit level for compiling aggregates related to high-technology, medium-high-technology, medium-low-technology and lowtechnology (see Annex 1).

Changes in dynamics of divisions/groups over the observed period and changes in the structure of manufacturing sector will serve as a tool for discovering the effectiveness of the conducted tech-intensity changes.

\section{Results and discussion}

First of all, it's important to note that the trend of a marked increase in Serbian manufacturing value added, expressed in euros, as recorded during 2016-2018 (Nikolić \& Zoroja, 2018), lost steam in 2019. According to the structural statistics data of the Statistical Office of the Republic of Serbia (SORS), the value added increased by $2.3 \%$ compared to 2018 , or 4,2 times less than in period 2018 2019. Despite that, the total manufacturing value added of the Republic of Serbia finally exceeded 6 billion euros in 2019 , which is $61,4 \%$ more than the created value at the beginning of the decade.

The situation is differentiated by manufaturing divisions and groups. it is easily noticeable that the three divisions contributed to this, somewhat weaker, result in 2019:

- Manufacture of chemicals and chemical products;

- Manufacture of motor $\mathrm{v}^{*}$ ehicles, trailers and semi-trailers; and, in particular,

- Manufacture of basic metals.

If their performance had remained at the level of 2018, the year-on-year growth of the total value added of the processing industry would not have been $2.3 \%$, but $6.1 \%$ in 2019. 
Industries grouped according to technological intensity have seen varied growth patterns in recent periods.

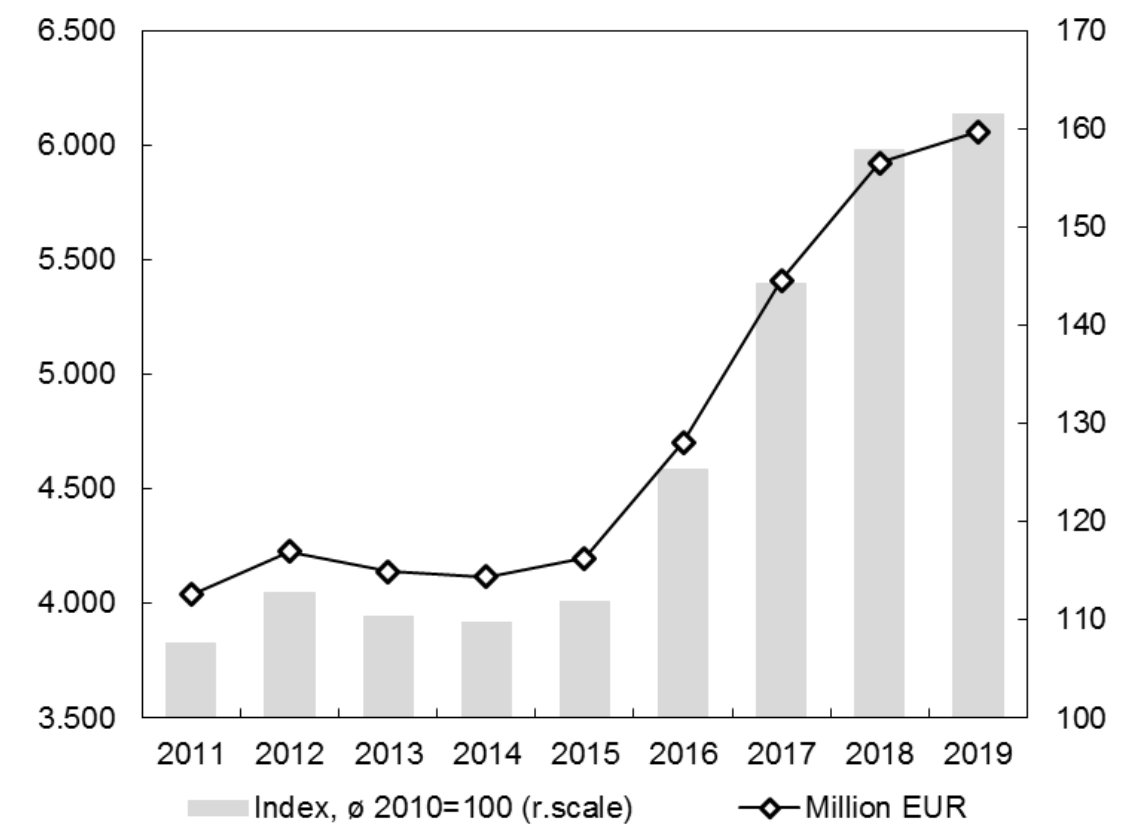

Figure 1. Manufacturing value added in Serbia

Source: Own calculations based on SORS data

It is evident that the disturbance in the first two divisions was reflected in the cessation of the pronounced expansion of the group of companies of mediumhigh technology. Here we register a barely slight year-on-year increase in value added. This is not good news given the fact that this segment of production has made a key contribution to the process of positive technological restructuring of total industry since 2015. Inter alia, the longest episode of expansive growth of the manufacturing sector since gross value added. The result of the third division, i.e. manufacture of base metals, translated the trend of added value of the group of companies of medium-low technological characteristics from growing to slightly declining. 


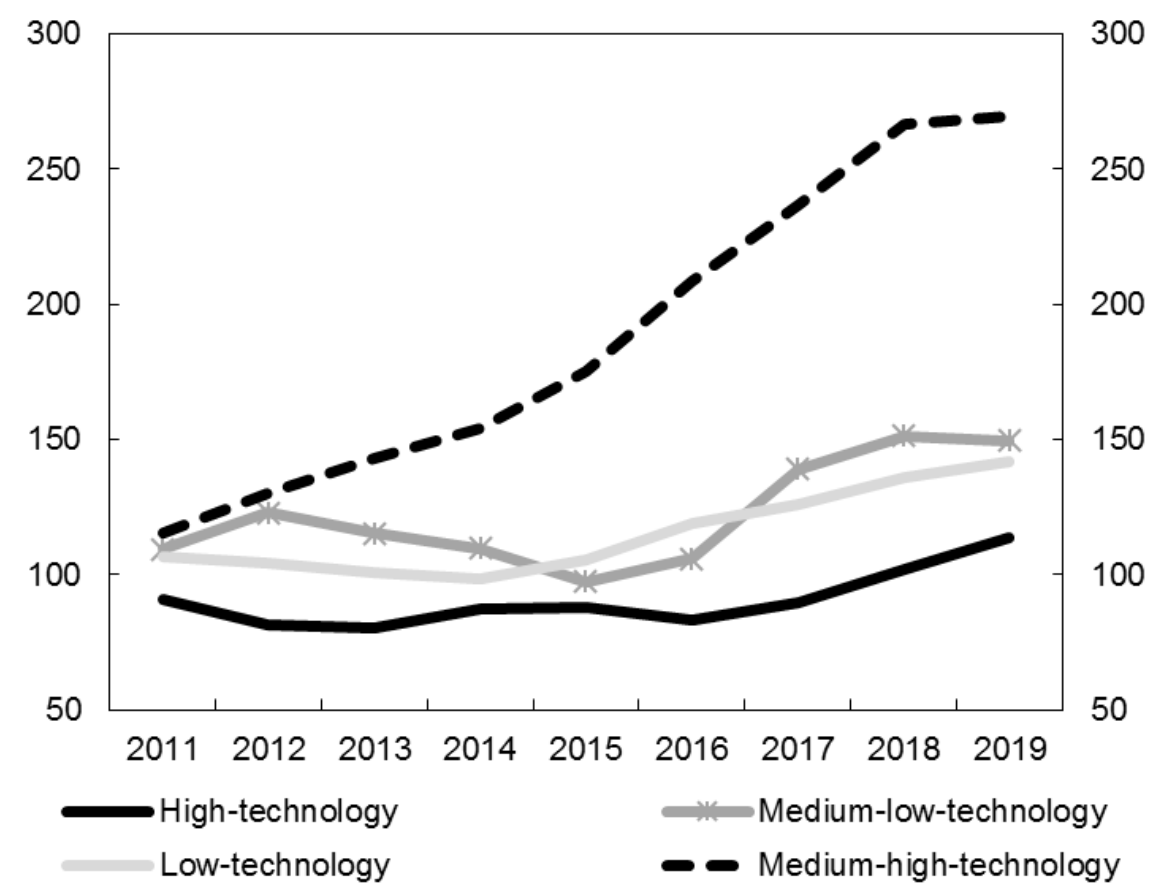

Figure 2. Growth of manufacturing industries by technological intensity (index, ø2010=100)

Source: Own calculations based on SORS data

The performance of high-tech industries as well as low-tech companies remained at a satisfactory level during 2019 , and their generated added value is still on a stable growth path from previous years.

Structural change represented by a shift towards high-technology manufacturing industries is evident and will play a key role in promoting innovation in the long term. Investment in new sustainable technologies continues to represent a major component in the generation of the innovation that is shaping the future of manufacturing in Serbia. 
Table 1. Technological intensity (value added stucture)

\begin{tabular}{ccccc}
\hline & $\begin{array}{c}\text { Low } \\
\text { technology }\end{array}$ & $\begin{array}{c}\text { Medium-low- } \\
\text { technology }\end{array}$ & $\begin{array}{c}\text { Medium-high- } \\
\text { technology }\end{array}$ & $\begin{array}{c}\text { High } \\
\text { technology }\end{array}$ \\
\hline $\mathbf{2 0 1 0}$ & $44,9 \%$ & $33,3 \%$ & $14,8 \%$ & $7,0 \%$ \\
\hline $\mathbf{2 0 1 1}$ & $44,4 \%$ & $33,9 \%$ & $15,8 \%$ & $5,9 \%$ \\
\hline $\mathbf{2 0 1 2}$ & $41,5 \%$ & $36,4 \%$ & $17,1 \%$ & $5,1 \%$ \\
\hline $\mathbf{2 0 1 3}$ & $40,9 \%$ & $34,8 \%$ & $19,1 \%$ & $5,1 \%$ \\
\hline $\mathbf{2 0 1 4}$ & $40,3 \%$ & $33,4 \%$ & $20,7 \%$ & $5,6 \%$ \\
\hline $\mathbf{2 0 1 5}$ & $42,3 \%$ & $29,0 \%$ & $23,2 \%$ & $5,5 \%$ \\
\hline $\mathbf{2 0 1 6}$ & $42,6 \%$ & $28,2 \%$ & $24,6 \%$ & $4,7 \%$ \\
\hline $\mathbf{2 0 1 7}$ & $39,2 \%$ & $32,2 \%$ & $24,3 \%$ & $4,4 \%$ \\
\hline $\mathbf{2 0 1 8}$ & $38,6 \%$ & $31,9 \%$ & $24,9 \%$ & $4,5 \%$ \\
\hline $\mathbf{2 0 1 9}$ & $39,5 \%$ & $30,9 \%$ & $24,7 \%$ & $5,0 \%$ \\
\hline
\end{tabular}

Source: Own calculations based on SORS data

In 2019, within manufacture of chemicals and chemical products, three of the five groups of activity recorded a reduction in value added. The key problem is group 20.1 - Manufacture of basic chemicals, fertilisers and nitrogen compounds, plastics and synthetic rubber in primary forms, where value added compared to 2018 decreased by $€ 35,5$ million (the decline was registered for the second year in a row, because during 2018. compared to 2017, the decline was $€ 18,3$ million). It is a known fact that the dynamics of the chemical industry - after a standstill in one part in 2018 and the first part in 2019 (due to investment and overhaul works in HIP Petrohemija) stabilized production at the end of 2019 (MAT, 2020). On the other hand, "HIP-Azotara Pancevo", the company for the production of artificial fertilizers and nitrogen compounds has been in trouble and bankruptcy for years (for example, during 2019, this company, according to Serbian Business Registers Agency, reported revenues from sales of products and services only $2 \%$ realizations from 2018 , but we also believe, with the completed merger of JP Srbijagas, which again does not belong to the processing sector but is registered as Trade, which methodologically complicates the analysis) (SBRA, 2020).

As for the division 29- Manufacture of motor vehicles, trailers and semi-trailers; and, in particular, the finding is somewhat surprising. We expected a continued decline in the newly created value in the Kragujevac car factory "FCA Serbia", which belongs to the group 29.1-Manufacture of motor vehicles, because the 
year-on-year decline in the physical volume of production of motor vehicles and trailers in the whole of 2019 amounted to $1 \%$. However, for the first time in this decade, we register more serious disturbances in the group 29.3-Manufacture of parts for motor vehicles and engines, where value added compared to 2018 decreased by $€ 25,7$ million (which explains $94 \%$ decline in value added of the whole division). The financial result, when represented by added value, a key component in the formation of gross domestic product, in this branch does not correspond to the registered physical volume of production, which here in 2019 increased by as much as $19,4 \%$ (this phenomenon is possible, especially in the short term. It concerns the profitability of production, because it is possible for production to take place in one period and inefficiently, due to e.g. deflation).

Group 29.1-Production of motor vehicles, similar to the (pre)mature production that comes out of the Kragujevac car factory in a way, is a pleasant surprise, because the newly created value here remained at around $€ 117$ million, which is within the three-year industry average.

There is no doubt that the automotive sector in Serbia is also affected by the dramatic earthquakes that have rocked the global market since 2017. The recession in the automotive industry deepened in 2019, with worldwide sales falling by more than $4 \%$, the world's largest vehicle market, where the slowdown in economic growth and the abolition of tax breaks for the purchase of electric cars reduced sales of new vehicles by 2,3 million compared to 2018. Overall, the industry faces a major challenge in the segment of discarding internal combustion engines as response to climate change. There is great uncertainty about how switching to electric vehicles will affect sales; to say nothing of the possibility that individual car ownership will gradually be replaced by fleets of autonomous cars providing rides on demand. Electric vehicles cost significantly more than classic models, requiring fewer workers when assembling and relying on dramatically shorter supply chains. On the other hand, the thesis that the world may have reached the "perfect car", that is, the point at which the global demand for vehicles begins to decline inexorably, is often emphasized. So, the fact is that serious problems in the automotive industry in the world manifested themselves long before the downturn brought by COVID-19. We must keep in mind that, according to the International Monetary Fund, the automotive industry accounts for $5,7 \%$ of global production and $8 \%$ of goods exports. It is the second largest consumer of steel and aluminum (IMF, 2019).

This is a good introduction to the results of the third problematic area of the Serbian manufacture industry - 24-Manufature of basic metals, but not in all its groups, but, above all, in 241- Manufacture of basic iron and steel and of ferroalloys. Here, after excellent two-year results, the added value collapsed again, with a negative sign of over $€ 91$ million. Simply put, this production, like many times in the past, has literally eaten up the newly created value generated by 
companies in the other two important groups of this field: Manufacture of basic precious and other non-ferrous metals and Casting of metals.

In addition to falling demand due to the recessionary pressure facing the global automotive industry and some other segments, a key factor in the industry's poor performance stems from quotas for steel imports into the EU. Namely, EU safeguard measures in the form of import quotas were imposing at the beginning of February 2019 and referred to 26 categories of steel products originating from countries outside the EU, including Serbia (Official Journal of the European Union, 2019/159). The quotas for steel imports to the EU have been increased, it is true, by about $5 \%$ since July, but that obviously did not significantly alleviate the problems.

On the other hand, this production was also faced with unfavorable price disparities, which raised costs. While the price of iron ore on the world market increased by about $60 \%$ compared to 2018 , at the same time there was a significant drop in the price of steel, which brought down the output value.

Table 2. Sectoral contribution to average value-added growth

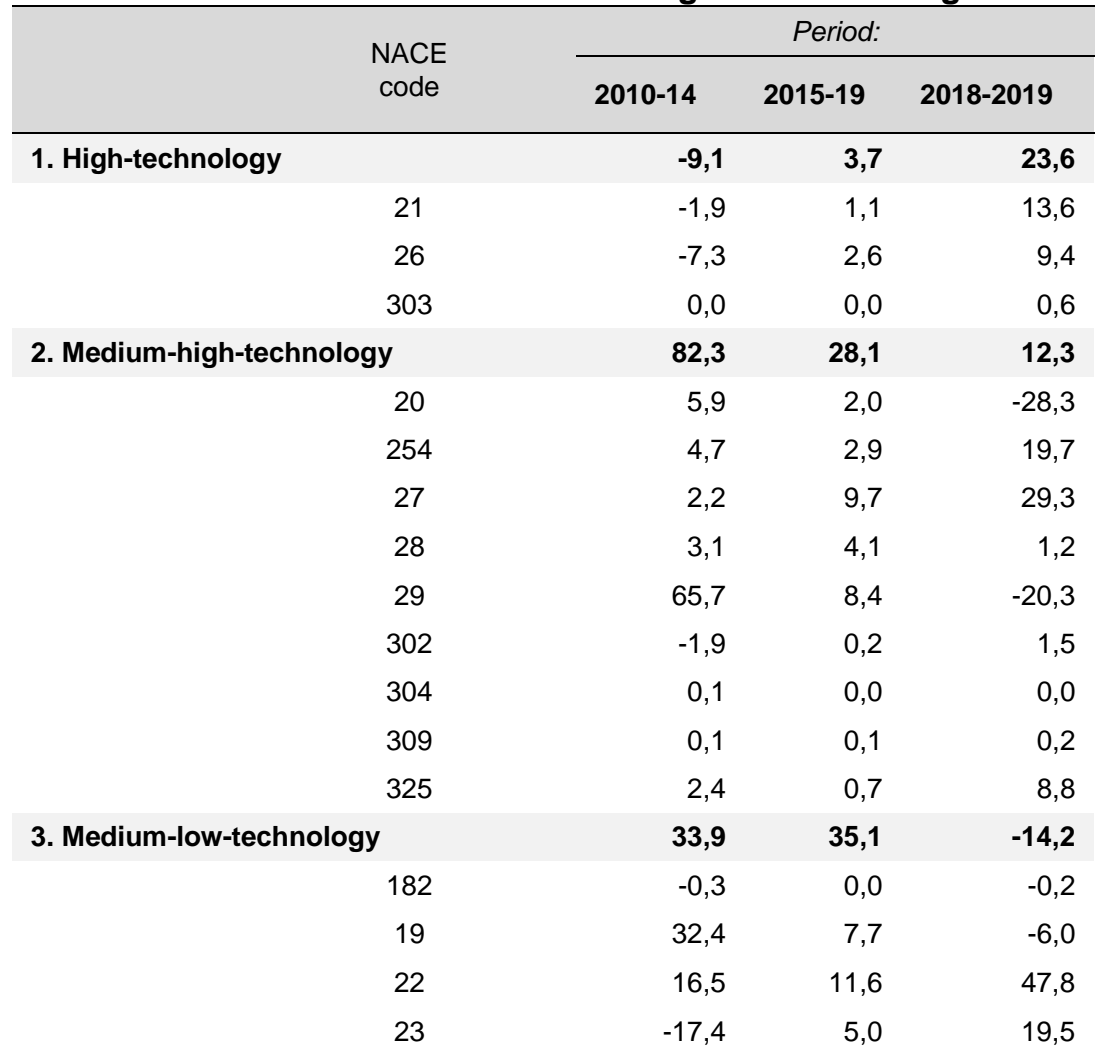

Industrija, Vol.48, No.4, 2020 


\begin{tabular}{rrrr}
24 & $-11,5$ & 0,4 & $-121,6$ \\
251 & 2,4 & 3,4 & 13,9 \\
252 & 0,4 & 0,8 & 1,7 \\
253 & $-0,2$ & 0,1 & 0,7 \\
255 & $-1,1$ & 0,3 & $-0,1$ \\
256 & $-0,9$ & 3,0 & 18,1 \\
257 & 4,4 & 0,7 & 9,2 \\
259 & 1,1 & 1,3 & 3,5 \\
301 & $-1,0$ & 0,3 & 0,6 \\
33 & 9,1 & 0,6 & $-1,1$ \\
& $-7,0$ & 33,1 & 78,3 \\
10 & $-9,3$ & 8,9 & 16,1 \\
11 & $-18,8$ & 2,7 & $-3,9$ \\
12 & $-0,3$ & 4,8 & 14,2 \\
13 & 5,7 & 1,8 & 6,9 \\
14 & 10,6 & 3,4 & $-1,5$ \\
15 & 0,7 & 2,7 & 7,1 \\
16 & 4,5 & 1,6 & 2,4 \\
17 & 3,9 & 2,2 & 9,1 \\
31 & $-2,8$ & 4,0 & 17,6 \\
other & $-1,3$ & 0,8 & 10,3 \\
\hline & 100 & 100 & 100 \\
\hline calculations based on SORS data &
\end{tabular}

One of the biggest structural problems of the economy is the slowness in changing the technological structure of the manufacturing sector in Serbia. During 2019, the share of high-tech production areas in the total added value increased to $5 \%$, which is the best result since 2015 . At the same time, mediumtech production account for $55,6 \%$ of the newly created value, while the share of low-tech increased from 38,6\% in 2018 to $39,5 \%$ in 2019 .

However, by crossing the newly created value with the performance of the observed units, which are classified according to technological complexity, we found that the key contribution to the growth of value added of the processing sector of $2,3 \%$ in 2019 came from low-tech production (exactly 1,78 percentage points). The areas of the most technologically complex segment of production follow (specifically, it is the group of production of computers, electronic and optical products where the production process is characterized by the design and use of integrated circuits, as well as the application of highly sophisticated 
technology), which contributed with 0.54 p.p. and the medium-high-technology group with $0,28 \mathrm{pp}$. The curiosity is that all components of the mentioned highest technological phase of production in 2019 ended with a double-digit growth of newly created value (division 21-Manufacture of basic pharmaceutical products and pharmaceutical preparations increased by $13,1 \%$, division 26-Manufacture of computer, electronic and optical products by $10 \%$, and value added in group 30.3-Manufacture of air and spacecraft and related machinery by as much as $27,5 \%)$.

Medium-low-tech, overall, in 2019 negatively contributed to the growth of the manufacturing sector, even with 0,32 percentage points. due to the fact that it recorded a decline in newly created value expressed in euros by about $1,0 \%$.

As mirror reflection, changes in production correspond to the movement in foreign trade. The coverage of imports by exports of the manufacturing industry, relatively observed in the medium term, is increasing the fastest in the segment of tangible production, which is included in the category of medium technological complexity.

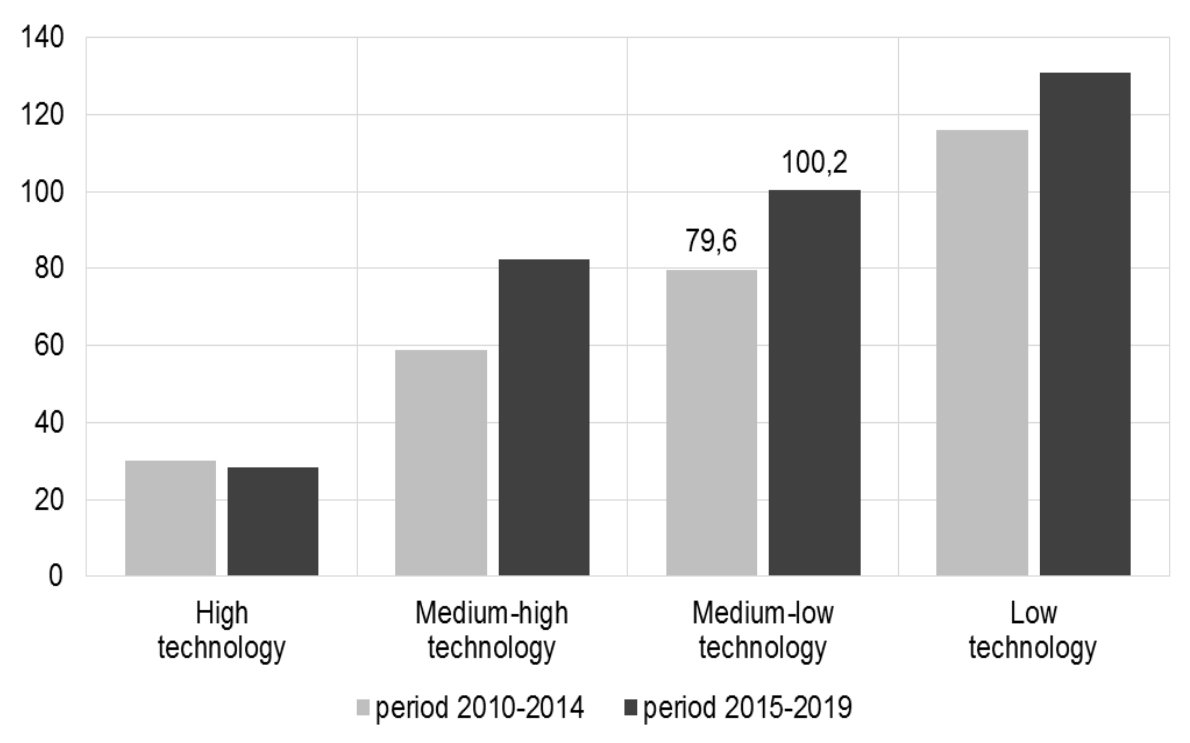

Figure 3. Manufacturing export-import ratio (exports as a \% of imports)

Source: Own calculations based on SORS data 
Serbia is not exclusively competitive in the labour intensive stages of production. It is also competitive in a good part of medium-technological complexity production (Figure 3 ).

However, the previous picture would be much better if we ignored the poor performance of two of the three divisions, from the beginning of the analysis. Namely, the total external trade deficit in division 24-Manufature of basic metals, division 20-Manufacture of chemicals and chemical products and division 19- Manufacture of coke and refined petroleum products amounted to $€ 596.4$ million in 2019 , while the total deficit of the manufacturing sector amounted to $€ 653.1$ million. Thus, as much as $91,3 \%$ of the increase in the external trade deficit of the manufacturing sector in 2019 comes from these three divisions.

The situation is seemingly the most difficult in the division of 24-Manufacture of base metals, where the surplus of over $€ 221$ million in 2018 turned into a deficit of $€ 32,5$ million. This is the result of higher imports, which stopped at $€ 1.713,9$ million ( $€ 240,4$ million more than in 2018), while exports remained at the level of 2018. Nevertheless, in contrast to the described results regarding added value, where the problem was located in group 24.1- Manufacture of basic iron and steel and of ferro-alloys, spoilage of the external trade balance originates from group 24.2- Manufacture of tubes, pipes, hollow profiles and related fittings, of steel. There, the deficit increased from $€ 39,8$ million to $€ 231,9$ million, or 6,8 times. As this disturbance is a consequence of the realization of the Turkish Stream project, which will be completed at the end of 2020 and operatively functional in 2021 , it is clear that there is no room for concern here.

Regarding the division 19- Manufacture of coke and refined petroleum products, the average annual trade deficit is in the period 2013-2018. steadily oscillated around $€ 335$ million. The deviation of more than $€ 151,1$ million in 2019 is incidental and originates from investment and repair works in company "Petrohemija-Pančevo", due to which its production was substituted by the import of finished derivatives. At the same time, the delay in the refinery had an equally unfavorable effect on the trade balance of group 20.1- Manufacture of basic chemicals, fertilisers and nitrogen compounds, plastics and synthetic rubber in primary forms, where the value of exports decreased by $€ 80,7$ million, imports increased by $€ 135,4$ million, and the deficit amounted to $€ 216,1$ million. The average annual value of the external trade deficit in the entire division 20Manufacture of chemicals and chemical products averages annually in this decade was around $€ 1.050$ million. The exceptions are exactly the years when the refineries were overhauled - that is 2012 and 2019, when the deficit increased to $€ 1.397$ million and $€ 1.219$ million, respectively. 


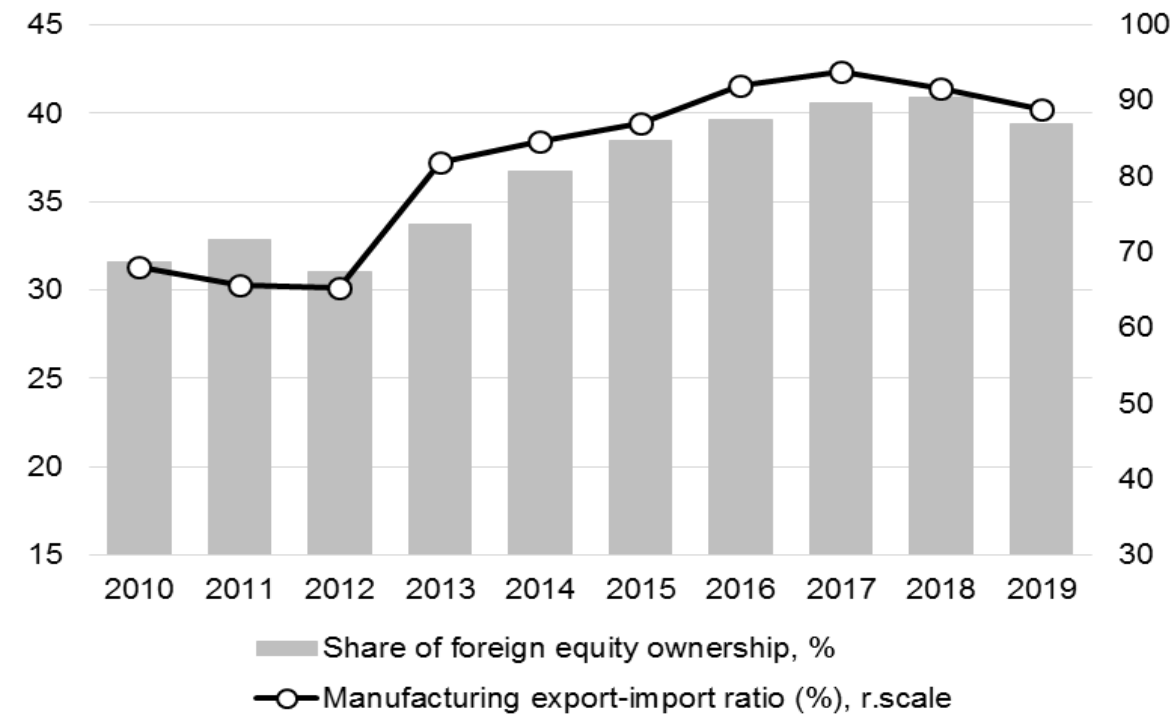

Figure 4. The effect of foreign equity ownership on export-import ratio Source: Own calculations based on SORS data

The updated SORS base with results for 2019 additionally supports the thesis of a high positive agreement between the closing of the external trade deficit and the increase in the share of foreign capital in the total ownership of the manufacturing sector.

Table 3. The share of foreign equity ownership in total capital of Serbian manufacturing, \%

\begin{tabular}{lcccccccccc}
\hline & $\mathbf{2 0 1 0}$ & $\mathbf{2 0 1 1}$ & $\mathbf{2 0 1 2}$ & $\mathbf{2 0 1 3}$ & $\mathbf{2 0 1 4}$ & $\mathbf{2 0 1 5}$ & $\mathbf{2 0 1 6}$ & $\mathbf{2 0 1 7}$ & $\mathbf{2 0 1 8}$ & $\mathbf{2 0 1 9}$ \\
\hline High-technology & 37,7 & 37,3 & 39,5 & 40,3 & 38,3 & 42,3 & 42,9 & 69,3 & 70,2 & 69,7 \\
Medium-high & 20,7 & 25,5 & 27,8 & 32,0 & 34,8 & 34,5 & 35,1 & 31,0 & 32,5 & 33,4 \\
Medium-low & 38,0 & 38,4 & 31,8 & 32,5 & 38,0 & 41,5 & 45,0 & 46,6 & 46,2 & 45,0 \\
Low-technology & 33,8 & 34,0 & 31,6 & 34,6 & 36,7 & 38,5 & 38,4 & 39,7 & 38,9 & 35,2 \\
\hline \multicolumn{7}{c}{ Source: Own calculations based on SORS data }
\end{tabular}

Another fact should be pointed out. For the first time since 2012, Serbia has halted the trend of increasing the share of foreign capital in the total capital value of the manufacturing sector. Thus, foreign ownership in the manufacturing increased more slowly than domestic. The stock of foreign

Industrija, Vol.48, No.4, 2020 
capital increased by $4 \%$, and domestic capital by $10,7 \%$. A result that will delight critics of state incentives to foreign investors, perhaps as much as the one on the expansion of the external trade deficit.

\section{Conclusions}

In recent years Serbia recorded a rising share of manufacturing in output and employment, specialization in manufacturing exports, and have experienced the strongest performance in terms of labour productivity growth. Nevertheless, in order to maintain the process of growth-enhancing structural transformation Serbia need to, even more powerful, deepen and broaden structural transformation and further build entrepreneurial and technological capabilities.

The structural problem of Serbia remains a low technological level of production that is not generating growth, or is manifested in a divergent trend of the physical volume and gross value added. It should be emphasized that Serbia holds the world record in relative export growth during the last several years. Again, despite visible improvement, industry and exports rely on lowtechnology, i.e. low-accumulation areas of production. They generate a surplus (good for the balance of payments), but they do not contribute to economic growth (Nikolić and Rajić,2019). Over and above, despite strong Serbian export growth in the first two decades of this century and moderate structural improvements, there are no conclusive signs of sufficient convergence to the EU import demand structure or sufficient growth of the share of goods at higher levels of processing in Serbian exports to imply the significant structural improvement of Serbia's trade, compared with CEE countries (Nikolić\&Nikolić, 2020).

Moreover, this paper underline that:

- During 2019, the share of high-tech production areas in the total value added increased to $5 \%$, which is the best result since 2015 . At the same time, medium-tech production account for $55,6 \%$ of the newly created value, while the share of low-tech increased from $38,6 \%$ in 2018 to $39,5 \%$ in 2019.

- Medium-low-tech, overall, in 2019 negatively contributed to the growth of the manufacturing sector, even with 0,32 percentage points.

- As mirror reflection, changes in production correspond to the movement in foreign trade. The coverage of imports by exports of the manufacturing industry, relatively observed in the medium term, is increasing the fastest in the segment of tangible production, which is included in the category of medium-technological complexity. 
- Serbia is not exclusively competitive in the labour intensive stages of production. It is also competitive in a good part of mediumtechnological complexity production.

- Vast FDI inflows i.e. the activities of foreign investors, in good part, drive successful technological restructuring in recent years.

Strengthening national educational systems is a common recommendation for effective response to rapid technological change (Romer, 1990). It's quite clear that the role of technologies for accelerated and sustainable development has become all the more pivotal in the post-COVID-19 scenario, as the fallout from the pandemic is likely to accelerate some facets of the ongoing process of industrial digitalization and servicification (UNCTAD, 2000a). Herein, substantial investments in science, technology and innovation infrastructure, institutions and human capital - all the underpinnings of sound innovation systems - must be an integral part of the immediate response to the COVID19 crisis and of the long-term effort to rebuild better and prepare for similar future challenges (UNCTAD, 2020). Efforts to strengthen science, technology and innovation resources in developing countries could distinguish between the needs of immediate responses and longer-term strategies. During the crisis, support for research and development should be included in emergency measures and $\neg$ scal recovery packages (UNCTAD, 2020b).

In this context, policymakers need to refocus on the role of industrial policy and its interaction and interdependence with a range of other sectoral policies, including the gendered dimensions of the digital divide, and the changing nature of production and sectoral interdependencies.

\section{References}

Castaldi, C., M. Cimoli, N. Correa \& G. Dosi, (2009). "Technological Learning, Policy Regimes, and Growth: The LongTerm Patterns and Some Specificities of a 'Globalized' Economy", in Industrial Policy and Development: The Political Economy of Capabilities Accumulation, edited by M. Cimoli, G. Dosi and J. Stiglitz, Oxford.

Cimoli, M. (1988), "Technological Gaps and Institutional Asymmetries in a NorthSouth Model with a Continuum of Goods", Metroeconomica, 39; 245 - 274.

Cimoli, M. \& Dosi, G. (1995), Technological Paradigms, Patterns of Learning and Development: An Introductory Roadmap. Journal of Evolutionary Economics, 5 (3), 242-268.

Commission Implementing Regulation (EU) 2019/1590. Official Journal of the European Union 1.2.2019

Foteini. K, \& Nelson, C. (2018). Industrial development in least developed countries. UNIDO- Working Paper 26/2018. 
Haraguchi, N., Martorano, B., \& Sanfilippo, M. (2018). What factors drive successful industrialization? Evidence andimplications for developing countries. Structural Change and Economic Dynamics, 49.

IMF (2019). World Economic Outlook, Global Manufacturing Downturn, Rising Trade Barriers, Chapter 1, October 2019

Kaldor, N. (1975). What is wrong with economic theory? Quarterly Journal of Economics, 89(3)

MAT-Macroeconomic Analysis and Trends, publisher Economics Intitute and Serbian Chambers of Commerce, 2020

Nikolić, G. \& Nikolić, I. (2020). The Structural Changes of the Serbian Merchandise Trade During Transition Process: Comparative Analysis of Main Trade Indicators, Ekonomika preduzeća, pp.383-399 doi:10.5937/EKOPRE $2006383 \mathrm{~N}$

Nikolić, I., \& Rajić, T. (2019). "Structural and Performance Analysis of Serbian SME Sector at an Aggregate and Individual Level", p. 339-375. in: How to prevent SMEs failure (Actions based on comparative analysis in Visegrad countries and Serbia). Visegrad+ Grant No. 21820267. University of Belgrade, Technical Faculty Bor, Engineering Management Department (EMD), 2019, ISBN 97886-6305-095-2; COBISS.SR-ID 276434956

Nikolić, I., \& Zoroja, M. (2018). What's Driving the Rapid Growth of Serbian Manufacturing Since 2014? Why Does Technology Matter? BH Economic Forum, Faculty of Economics - University of Zenica, ISSN: 1986-681X, year 2018, no. 9/2018, pp. 29-41.

OECD. (2011). ISIC REV. 3 Technology Intensity Definition - Classification of manufacturing industries into categories based on R\&D intensities, p. 6, 7 July, 2011.

Romer, P. (1990). Endogenous technological change. Journal of Political Economy. 98(5 pt 2), S71-102

SBRA - Serbian Business Registar Agency Registar, 2020 Available at: https://www.apr.gov.rs/registers/companies.1786.html

UNCTAD (2020). The need to protect science, technology and innovation funding during and after the COVID-19 crisis. Policy Brief No. 80.

UNCTAD (2020a). The LCD REPORT 2020 - Productive capacities for the new decade. United Nations Publications, p.196

UNCTAD (2020b). Impact of COVID-19 Pandemic on Trade and Development Transitioning to a New Normal, United Nations Publications, p.113.

UNIDO (2020). COVID-19 Implications \& Responses - Digital Transformation \& Industrial Recovery, June 2020, p. 23.

World Economic Forum. (2017). White Paper - Technology and Innovation for the Future of Production: Accelerating Value Creation, p. 38. 